SHORT REPORTS

\section{Critical evaluation of 24-hour urinary oestriol estimation in clinical practice}

Of all the biochemical methods of assessing placental function, measurement of 24-hour urinary oestriol concentrations is probably the most widely used. Many reports confirm that oestriol concentrations are of predictive value in high-risk pregnancies ${ }^{1-3}$ and show that abnormal values are of statistical significance in selecting highrisk groups of patients. There is, however, a difference between statistical and clinical significance, ${ }^{2}$ and many obstetricians do not use oestriol values in the way that they have been used in various trials.

We do not routinely measure oestriol concentrations, or perform any other test, on all patients. Those patients considered to be at risk of intrauterine growth retardation are investigated by several methods (oestriol estimation, kick charts, serial scanning, etc) to attempt to detect growth retardation in an individual case. Clinical indications for further study of an individual patient include: a previous growth-retarded or clinically small baby, poor weight gain, hypertension, pre-eclamptic toxaemia, diabetes, antepartum haemorrhage, and twins. Patients investigated on an outpatient basis have 24-hour urinary oestriol concentrations estimated each week if possible and inpatients twice a week. We try to perform serial investigations whenever possible.

\section{Patients, methods, and results}

The notes of all patients who had stillbirths and those whose babies were born weighing less than the 10th centile for their gestational age ${ }^{4}$ in the first six months of 1979 were reviewed to determine the cause of fetal death, the clinical management of the patient, and the 24-hour urinary oestriol results. All our patients with less than certain menstrual data have an early ultrasound scan. Oestriol concentrations in our laboratory are measured on an aliquot from a 24-hour urine specimen according to the method of Cambell and Gardner. ${ }^{5}$

In the period under study there were 1835 births, of which 12 were stillbirths. The laboratory performed 6970 24-hour urinary oestriol estimations in this time. One hundred and twenty-four babies had weights below the 10th centile and were defined as light for dates; in 62 of these cases oestriol values were not measured because there were no clinical indications. Forty had serial oestriol estimations. Of the 84 patients who did not have serial measurements, 19 had some other obstetric problem necessitating urgent intervention (such as severe pre-eclamptic toxaemia). Of the 62 patients who had oestriol values measured, 51 had unequivocally normal results, eight had falling values, and three had steady low values. In five patients the low or falling oestriol values contributed to the decision to deliver, but in 20 cases a decision to deliver was made on the grounds of suspected intrauterine growth retardation in the face of normal oestriol values.

Two pregnancies that resulted in small-for-dates stillbirths were monitored by serial oestriol measurements.

Case 1-This patient was known to have a uterus didelphys. She had previously had a vaginal septum divided and the diagnosis had been established by laparoscopy. Her baby was clinically small for dates from 34 weeks in her first pregnancy and she was monitored as an outpatien with weekly 24-hour urinary oestriol mcasurements, which were all normal. The last value of $113 \mu \mathrm{mol} / 24 \mathrm{~h}(32.5 \mathrm{mg} / 24 \mathrm{~h})$ was measured in urine collected the day before fetal death occurred in utero.

Case 2-This patient had poor weight gain at 36 weeks' gestation in her first pregnancy. She had two urinary oestriol estimations performed a 38 weeks and 40 weeks, which gave values of $78 \mu \mathrm{mol} / 24 \mathrm{~h}(22.5 \mathrm{mg} / 24 \mathrm{~h})$ and $82 \mu \mathrm{mol} / 24 \mathrm{~h}(23.6 \mathrm{mg} / 24 \mathrm{~h})$ respectively. The last value was received on the day that the patient presented with an intrauterine death.

\section{Comment}

Criticism can be made of the way that we use oestriol values. Nevertheless, it is the way that many other units use them to monitor at-risk pregnancies. Many authors have pointed out that serial values are better than single results, ${ }^{1-3}$ while others have suggested that oestriols should be used as a routine screen on all patients. ${ }^{1}$

I would suggest that to perform over 6000 tests on 1853 patients for only five positive contributions to correct management is poor medicine. When we consider that two patients lost their babies in the face of normal oestriol values and that in one case reliance on these normal values contributed to the death, then the value of measuring oestriol concentrations in the detection and management of smallfor-dates foetuses is even more questionable.

${ }^{1}$ Beisher NA, Brown JB. Current status in oestrogen assays in obstetrics and gynaecology. Part 2 Oestrogen assays in late pregnancy. Obstet Gynecol Surv 1972;27:303-43.

2 Barnard WP, Logan WR. The value of urinary oestriol estimation in predicting dysmaturity. Fournal of Obstetrics and Gynaecology of the British Commonwealth 1972;79:1091-4.

3 Beisher NA, O'Sullivan EF. The effect of rest and intravenous infusion of hypertonic dextrose on subnormal estriol excretion in pregnancy. Am ₹ Obstet Gynecol 1972;113:771-8.

4 Gairdner D, Pearson J. A growth chart for premature and other infants. Arch Dis Child 1971 ;46:783-7.

5 Cambell DC, Gardner G. The automatic analysis of urinary oestrogens during pregnancy. Clin Chem Acta 1971;32:153-7.

(Accepted 2 fanuary 1980)

\section{Addenbrooke's Hospital, Cambridge}

E J SHAXTED, MRCOG, registrar in obstetrics and gynaecology (present appointment: senior registrar in obstetrics and gynaecology, Nottingham City Hospital, Nottingham).

\section{Mazindol-induced lithium toxicity}

Some patients taking lithium gain weight. ${ }^{1}$ The reason for this is unknown. Dieting may help ${ }^{2}$ but should be undertaken carefully since it may cause lithium toxicity. ${ }^{3}$ We report a case in which lithium toxicity was apparently precipitated by the anorexiant mazindol.

\section{Case report}

A 58-year-old woman, who had suffered from manic depressive psychosis for 18 months, was treated with lithium carbonate $300 \mathrm{mg}$ thrice daily for 15 months. Her serum lithium concentration, measured monthly, was consistently within the therapeutic range of $0.4-1.3 \mathrm{mmol} / 1(0.28-0.90$ $\mathrm{mg} / 100 \mathrm{ml}$ ). She responded favourably and her bipolar symptoms regressed. She had been gaining weight for 15 months and was eventually given mazindol $2 \mathrm{mg}$ daily. No dietary advice was given nor had she consciously restricted her fluid or food intake. Three days after she started mazindol her husband noticed that she had become apathetic, sluggish, and progressively ataxic. She continued to take both lithium and mazindol for another six days. When admitted to hospital the next day she was stuporose and had coarse twitching of the muscles of the left side of the face and righ hand, a widespread muscle fasciculation, and limb rigidity. She was dehydrated. Her pulse rate was $100 \mathrm{~min}$, and blood pressure $110 / 70 \mathrm{~mm} \mathrm{Hg}$ haemoglobin $13.5 \mathrm{~g} / \mathrm{dl}$, white cell count $10.2 \times 10^{9} / 1\left(10200 / \mathrm{mm}^{3}\right)$ with a normal differential, and erythrocyte sedimentation rate (Westergren) $7 \mathrm{~mm}$ in $1 \mathrm{~h}$, blood urea $15.5 \mathrm{mmol} / 1(93 \mathrm{mg} / 100 \mathrm{ml})$, serum creatinine $93 \mu \mathrm{mol} / 1$ $(0.9 \mathrm{mg} / 100 \mathrm{ml})$, serum lithium was $3.2 \mathrm{mmol} / 1(2.2 \mathrm{mg} / 100 \mathrm{ml})$, serum potassium $3.5 \mathrm{mmol}(\mathrm{mEq}) / 1$, and serum sodium $140 \mathrm{mmol}(\mathrm{mEq}) / 1$. Thyroid function tests were normal. The electrocardiogram (ECG) showed widespread ST-segment and T-wave abnormality. A chest radiograph was normal.

The patient was rehydrated and treated by an alkaline diuresis using mannitol and sodium lactate. On this regimen the serum lithium fell to $1.8 \mathrm{mmol} / 1(1.26 \mathrm{mg} / 100 \mathrm{ml})$ at 24 hours and $0.8 \mathrm{mmol} / 1(0.56 \mathrm{mg} / 100 \mathrm{ml})$ at 48 hours. Seven days after admission she was fully mobile, orientated, and without neurological signs. At 10 days the ECG had returned to normal. A creatinine clearance two weeks after admission was $90 \mathrm{ml} / \mathrm{min}$.

\section{Comment}

Lithium intoxication is a dangerous condition. In one series ${ }^{4}$ of 23 patients two died, two had persistent neurological sequelae, and 18 transient ECG abnormalities. The mechanism of intoxication is ill-understood, but when information is available renal impairment or factors influencing water and electrolyte balance have preceded toxicity. ${ }^{4}$ Mazindol has been reported to be an effective and welltolerated appetite suppressant, ${ }^{b}$ though its effective duration of 
activity may be limited. Unwanted effects, reflecting its central and autonomic nervous system activity, include insomnia, nervousness, dry mouth, constipation, and excessive sweating. These would not induce toxicity and it seems in our case that mazindol's anorexic activity caused the intoxication.

${ }^{1}$ Schou M, Baastrup PC, Grof P, et al. Pharmacological and clinical problems of lithium prophylaxis. $B r \mathcal{F}$ Psychiatry 1970;116:615-9.

${ }^{2}$ Dempsey M, Dunner DL, Fieve RR, Farkas I, Wong J. Treatment of excessive weight gain in patients taking lithium. Am $\mathcal{f}$ Psychiatry $1976 ; 133(9): 1082-4$

${ }^{3}$ Furlong FW. Lithium toxicity occurring with a "reducing" diet. Can Psychiatr Assoc F 1973;18:75-6.

${ }^{4}$ Hansen HE, Amdisen A. Lithium intoxication (Report of 23 cases and review of 100 cases from the literature). $Q 7 \mathrm{Med} 1978 ; 47(186): 123-44$

5 Defelice EA, Chaykin LB, Cohen A. Double-blind clinical evaluation of mazindol, dextroamphetamine and placebo in treatment of exogenous obesity. Curr Ther Res 1973;15:358-66.

(Accepted 16 fanuary 1980)

Department of Medicine, Basingstoke District Hospital, Basingstoke, Hants RG24 9NA

M S HENDY, MRCP, registrar

A F DOVE, MB, CHB, registrar

P G ARBLASTER, FRCP, consultant physician

\section{Intravenous methylprednisolone in minimal change nephrotic syndrome}

Prendisone by mouth in large doses usually reverses minimal change nephrotic syndrome but there may be severe side effects, particularly in patients with frequent relapses. We therefore tried a new regimen beginning with three consecutive pulses of intravenous methylprednisolone and following these with prednisone by mouth in low doses.

\section{Case reports}

Eleven patients aged from 4 to 46 were admitted to the study. All had a nephrotic syndrome defined on the basis of hypoalbuminaemia $(\leqslant 25 \mathrm{~g} / \mathrm{l})$ and proteinuria $\left(\geqslant 40 \mathrm{mg} / \mathrm{m}^{2} / \mathrm{h}\right.$ ). Renal biopsy specimens from seven patients by light and electron microscopy showed minimal glomerular changes. All patients had highly selective proteinuria as assessed by the clearances of IgG and transferrin. Remission was defined as three consecutive days without proteinuria and relapse as finding proteinuria $\left(\geqslant 4 \mathrm{mg} / \mathrm{m}^{2} / \mathrm{h}\right)$ on three consecutive examinations within seven days. Patients were classified as frequent relapsers if they relapsed more than once within six months of their first response or four times within any one year. ${ }^{1}$

Methylprednisolone $(15-20 \mathrm{mg} / \mathrm{kg})$ was given intravenously over $20-30$ min every $24 \mathrm{~h}$ for three consecutive days. After this prednisone $\left(20 \mathrm{mg} / \mathrm{m}^{2} / 24 \mathrm{~h}\right)$ was given by mouth for four weeks. The dose was then reduced to $20 \mathrm{mg} / \mathrm{m}^{2}$ every other day. This continued for five months and then progressively tapered off and stopped. In patients who relapsed the regimen was restarted.

All the patients had a complete remission, generally within 10 days (table). Three relapsed after 28,180 , and 380 days. They responded to a new course of intravenous methylprednisolone and had no further relapses. Two patients complained of flushing during methylprednisolone infusion, but it ceased a few minutes after the infusion stopped. No sign of hypercorticism, infections, or other complications referable to corticosteroids were observed.

\section{Comment}

Treatment with $60 \mathrm{mg} / \mathrm{m}^{2} /$ day prednisone by mouth for a few weeks may obtain a remission of the nephrotic syndrome in most patients with lipoid nephrosis. This regimen is generally well tolerated but signs of hypercorticism may develop. Moreover, many patients relapse and treatment has to be lengthy, increasing the risk of severe side effects and even death. ${ }^{2}$ On the other hand, patients with frequent relapses respond abnormally to ACTH. ${ }^{3}$ This suppression of the hypothalamic-pituitary-adrenal axis, possibly induced by protracted prednisone treatment in high dosage, might promote a relapse. The best schedule of steroid administration in lipoid nephrosis is therefore still uncertain.

The urine became protein free in all our patients and a remission was reached even in frequent relapsers. Three patients with heavy proteinuria in relapse rapidly responded to further treatment with intravenous methylprednisolone. None of our patients suffered from hypercorticism or other side effects. These preliminary results seem to indicate that our regimen might be effective and well tolerated in most patients with lipoid nephrosis.

${ }^{1}$ Abramowicz M, Arneil GC, Barnett HL, et al. Controlled trial of azathioprine in children with nephrotic syndrome. A report of the international study of kidney disease in children. Lancet 1970;i:959-61.

2 Arneil GC, Lam CN. Long-term assessment of steroid therapy in childhood nephrosis. Lancet 1966;ii:819-21.

${ }^{3}$ Leisti S, Hallman N, Koskimies O, Perheentupa J, Rapola J, Vilska J. Association of postmedication hypocortisolism with early first relapse of idiopathic nephrotic syndrome. Lancet 1977;ii:795-6.

(Accepted 27 November 1979)

Divisione di Nefrologia e Dialisi, Via della Commenda 15, Ospedale Policlinico, 20122 Milano, Italy

CLAUDIO PONTICELLI, $M D$, chief of unit

ENRICO IMBASCIATI, MD, assistant in nephrology

NADIA CASE, $M D$, assistant in nephrology

Divisione di Nefrologia e Dialisi, Via Palagi 9, Ospedale M Malpighi, 40138 Bologna, Italy

PIETRO ZUCCHELLI, $M D$, professor of medicine and chief of unit LEO CAGNOLI, MD, assistant in nephrology SONIA PASQUALI, MD, assistant in nephrology

\section{Oral contraceptives and pituitary adenomas}

An association between oral contraception and prolactin-secreting pituitary adenomas has been suggested by several recent studies. Sherman et al, ${ }^{1}$ for example, reported that 30 out of 42 women with amenorrhoea and hyperprolactinaemia who were surgically treated for a pituitary adenoma had taken oral contraceptives for an average of 2.4 years. Hardy et $a l^{2}$ found that 60 out of 80 patients with surgically proved prolactinoma had used oral contraception. Reports such as these prompted us to examine the relevant data accumulated in the two major British prospective surveys of women using oral contraception-namely, the Royal College of General Practitioners' (RCGP) study and the Oxford/Family Planning Association (FPA) study. Both of these studies began in 1968 and have been described elsewhere. ${ }^{3}{ }^{4}$

Results in 11 patients with minimal change nephrotic syndrome treated with modified corticosteroid regimen

\begin{tabular}{|c|c|c|c|c|c|c|c|}
\hline Case No & $\begin{array}{l}\text { Age (years) } \\
\text { and sex }\end{array}$ & $\begin{array}{c}\text { Episode of } \\
\text { nephrotic syndrome }\end{array}$ & Response to treatment & $\begin{array}{c}\text { Duration of } \\
\text { remission (days) }\end{array}$ & Relapse & $\begin{array}{c}\text { Response to } \\
\text { treatment }\end{array}$ & $\begin{array}{l}\text { Duration of } \\
\text { remission (days) }\end{array}$ \\
\hline $\begin{array}{r}1 \\
2 \\
3 \\
4 \\
5 \\
6 \\
7 \\
8 \\
9 \\
10 \\
11\end{array}$ & $\begin{array}{rl}9 & M \\
11 & M \\
8 & F \\
12 & M \\
22 & F \\
46 & F \\
5 & M \\
4 & M \\
16 & M \\
22 M \\
12 M\end{array}$ & $\begin{array}{c}\text { Frequent relapser } \\
\text { Frequent relapser } \\
\text { First } \\
\text { Frequent relapser } \\
\text { Second } \\
\text { First } \\
\text { First } \\
\text { First } \\
\text { Frequent relapser } \\
\text { Second } \\
\text { First }\end{array}$ & $\begin{array}{l}\text { Remission } \\
\text { Remission } \\
\text { Remision } \\
\text { Remission } \\
\text { Remission } \\
\text { Remission } \\
\text { Remission } \\
\text { Remission } \\
\text { Remission } \\
\text { Remission } \\
\text { Remission }\end{array}$ & $\begin{array}{r}700 \\
380 \\
455 \\
180 \\
270 \\
28 \\
230 \\
210 \\
180 \\
150 \\
150\end{array}$ & $\begin{array}{l}\text { No } \\
\text { Yes } \\
\text { No } \\
\text { Yes } \\
\text { No } \\
\text { Yes } \\
\text { No } \\
\text { No } \\
\text { No } \\
\text { No } \\
\text { No }\end{array}$ & $\begin{array}{l}\text { Remission } \\
\text { Remission } \\
\text { Remission } \\
\text { = } \\
\text { = } \\
\text { - }\end{array}$ & $\begin{array}{l}\overline{300} \\
\overline{180} \\
\overline{240} \\
= \\
= \\
=\end{array}$ \\
\hline
\end{tabular}

